\title{
Livelihood Strategies as Responses to Water Availability In Pusur Sub-watershed, Bengawan Solo Watershed
}

\author{
Rathna Wijayanti ${ }^{1}$, M. Baiquni ${ }^{2}$, and Rika Harini ${ }^{2}$ \\ 1)Program S3 Ilmu Lingkungan, UGM, Yogyakarta \\ ${ }^{2}$ Fakultas Geografi, UGM, Yogyakarta \\ Corresponding author (e-mail: wijayanti.rathna@yahoo.com)
}

\begin{abstract}
Water availability has a significant role on human life, particularly for the rural, agrarian communities. This study aimed to investigate the diverse conditions of water availability in Pusur sub-watershed, Bengawan Solo watershed, and the livelihood strategies of the localcommunity in responding to the water availability. The study used both quantitative and qualitative methods of data analysis, and the data was collected through questionnaire, in-depth interview, and observation. On the water availability, the study used the following variables: (1) quality, (2) quantity, (3) spatial and temporal distribution, (4) access, (5) social-economy, and (5) institutional aspect. On the livelihood strategies, it uses: (1) reaction and (2) anticipation for water deficit. In term of sampling methods, the study used area and purposive sampling, by splitting the study site into the upper, middle, and lower area. The analysis of this study indicates that the level of water availability in the upper area is considered low. The community living in the upper area depends upon rainwater for its agricultural sector, and upon the water supply distributed by pipelines and tanker trucks for its household. The study also indicates that the middle area has abundant water supply, but the quality has been declined due to pollution, poor sanitation system, and potential conflict among the community members. Meanwhile, in the lower area, particularly in the dry season, irrigation water has been inadequate. Responding to the diverse water availability, the community has applied the following livelihood strategies: (1) leaving the agricultural land uncultivated in the upper area, and (2) pumping wells and rivers in the middle and lower areas. In addition, as part of its precautions actions, the community has applied: (1) agroforestry system at the upper area, (2) improved the irrigation system of the middle area, and (3) creating wells and using water pumps in the lower area.
\end{abstract}

Keywords: livelihood strategies, water availability, watershed.

Abstrak. Ketersediaan air sangat mempengaruhi penghidupan, terutama pada masyarakat agraris pedesaan. Penelitian bertujuan mengkaji variasi ketersediaan air dan strategi penghidupan masyarakat terkait ketersediaan air di Sub DAS Pusur, DAS Bengawan Solo. Metode area sampling dan purposive sampling digunakan membagi daerah penelitian menjadi tiga berdasarkan dominasi penggunaan lahan dan sumber air untuk irigasinya, yaitu bagian atas, tengah, dan bawah. Variabel penelitian meliputi kualitas, kuantitas, distribusi spasial dan temporal, akses, sosial ekonomi, dan kelembagaan. Pengumpulan data menggunakan kuisioner terhadap 102 responden dan wawancara mendalam terhadap 31 key person. Analisis dilakukan secara kualitatif dan kuantitatif. Hasil penelitian menunjukkan pada bagian atas ketersediaan air sangat sulit, pertanian tergantung pada air hujan, kebutuhan domestik dipenuhi dari sumur air tanah dalam yang dibeli melalui jaringan pipa atau mobil tangki. Bagian tengah air melimpah namun kualitasnya menurun akibat pencemaran dan buruknya sistem sanitasi, serta konflik antar pengguna air. Bagian bawah, air irigasi pada musim kemarau tidak mencukupi. Strategi penghidupan berupa tindakan reaksi apabila terjadi ketidakcukupan air yaitu membiarkan lahan tidak ditanami untuk bagian atas, memompa air sumur maupun sungai untuk lahan pertanian bagian tengah dan bawah. Tindakan antisipasi berupa sistem agroforestry pada bagian atas, perbaikan/pemeliharaan saluran irigasi pada bagian tengah, serta menyiapkan sumur dan pompa pada bagian bawah.

Kata kunci: Strategi penghidupan, ketersediaan air, DAS. 


\section{Introduction}

Livelihood strategies represent the community's efforts to attain sustainable livelihoods. They are concerned with how people manage or combine the provided or possessed assets, face the prevailing changes, and set priorities to maintain or improve livelihoods (Scoones, 1998; Scale Up 2011). At the household level, livelihood strategy is an understanding on how households are capable to manage and take benefits from resources and capital assets through specific and selected activities (Baiquni, 2006). The changes of water availability at Pusur sub-watershed in their relation with livelihoods, had urged people to pile up strategy in adapting the condition in the form of reactions and anticipations.

Pusur sub-watershed is administratively included in two districts, namely Boyolali district $(19.80 \%)$ and Klaten district $(80.20 \%)$, Central Java Province. It is 5781.87 ha, which is a part of the Bengawan Solo watershed, consisting of sixty villages in eight districts. The major livelihood is farmer $(70 \%)$ that makes Pusur sub-watershed has a strategic role in the water system. The outflow is the main source of irrigation for farmers since the largest water demand is agricultural sector, which ranges from $69 \%-80 \%$ of total water demand (Harsoyo, 2011). In the development, there is a livelihood vulnerability related to water availability for the community. It is a latent situation that can change or affect people's livelihoods at any moment (DFID, 2001). One of the indicators is the rise of conflicts among the community as water users and the increased number of wellbore for irrigation in Pusur sub-watershed, which is well-known as granary area.

FAO (2007) stated that population growth and the development of agricultural and industrial sectors had led to the increase of water demand for domestic, agriculture, and industry. Enhanced water demand in Pusur sub-watershed was mainly due to population and industrial augmentation that were not balanced by serious concern in water availability aspect. Water allocation and distribution among sectors and among regions were increasingly complex with higher potential conflicts (Sosiawan and Subagyono, 2009).

Major concern in the water availability is variability (Khan, 2014). Pusur sub- watershed has elongated shape that involves various activities of community. It also had varied level of water availability within a year. In the rainy season, water was inclined to be plentiful and on the contrary it endured water deficit in the dry season. Nevertheless, water demand was stable which led to water deficit in the dry season.

Social, economic, and institutional element have important role in the watershed management (Perdirjen RLPS MoF, 2009). Socio-economic and institutional circumstances encouraged the community participation to cooperatively address the issue of livelihood vulnerability, which eventually improved the welfare of local community. Well-established institution would ensure the sustainability of water consumption.

In facing the changes, in terms of vulnerability, Winarto (2013) claimed that there are two primary measures, namely mitigation and adaptation. Mitigation is principally active actions to prevent and inhibit the changes, while adaptation is natural process carried out by human and other living things in a habitat and an ecosystem as reaction to the prevailing changes. Furthermore, adaptation is divided into two, which are reactive/responsive and proactive/anticipatory. In the context of climate change in Indonesia, particularly the issue of water resources, the Policy Brief World Bank (2010) propounded several options for adaptation including the management improvement and system maintenance of existing water resources, the improvement of water supplies, and the conservation of water catchment areas.

The problems in Pusur sub-watershed comprised of the imbalance of water demand and water availability, water deficit in the dry season, conflicts among the community, the social-economic gap, and institutional aspects that resulted a variety of livelihood vulnerability in Pusur sub-watershed.

Livelihoods consist of assets, activities, and access that simultaneously determine one's or household's life (Ellis, 2000). An attempt to confront livelihood vulnerability in terms of water availability, particularly farmers as vulnerable group that are highly dependent on water, is adaptation to water availability for sustainable livelihoods. Adaptation should be done both reactive or anticipatory (Winarto, 2013; World Bank, 2010). Sustainable livelihoods are the capacity to cope with and recover from stress and shocks, maintain capabilities and assets, and provide livelihood opportunities for the next generation (Chambers \& Conway, 1992). Therefore, this study aimed to investigate diverse vulnerabilities of livelihoods related to water availability, and to examine the 
community strategies in addressing those vulnerabilities.

\section{Research Methods}

This study employed qualitative and quantitative methods. Area sampling technique was used to determine the dominance of land use and irrigation sources for agricultural sector. Furthermore, the study site was divided into three, namely the upper, middle, and lower area (Figure 1). Purposive sampling was preferred to select the villages. The results were: Sukorejo village dominated by rain-fed dryland agriculture as the representation of upper area, Keprabon village dominated by full-year irrigated paddy fields as the representation of middle area, and Taji village dominated by paddy fields with mixed irrigation sources including irrigation, rain-fed, and pump as the representation of lower area. Study population was the households in the study site.

Primary data were obtained from structured interview, in-depth interview, observation, and documentation. Structured interview was in the form of questionnaire with 102 households as respondents from three villages in the study area. Respondents were selected based on random sampling technique. It was based on the parameter in which minimum number of sample is $10 \%$ of the population for descriptive study, 30 objects for correlation study, 30 subjects per group for causal comparison study, and 15 subjects per group for experimental study (Gay and Diehl (1992), Frankel and Wallen (1993), in Eureka Pendidikan, 2015). Farmer households were opted since they were the highest water consumers. In-depth interviews were conducted on 31 key persons who were presumed to provide information related to the research objectives. In addition to primary data, secondary data were obtained from library research released by both research agencies and government institutions.

The data were analyzed qualitatively and quantitatively. The data analysis technique was quantitative descriptive carried out by data input and the percentage of respondent' answers. The percentage demonstrated the majority of respondents' option. Qualitative analysis technique was used to interpret the data in accordance to research objectives as derived from questionnaires, interviews, and observations, in addition to describe a phenomenon and to cross check the results of questionnaire.

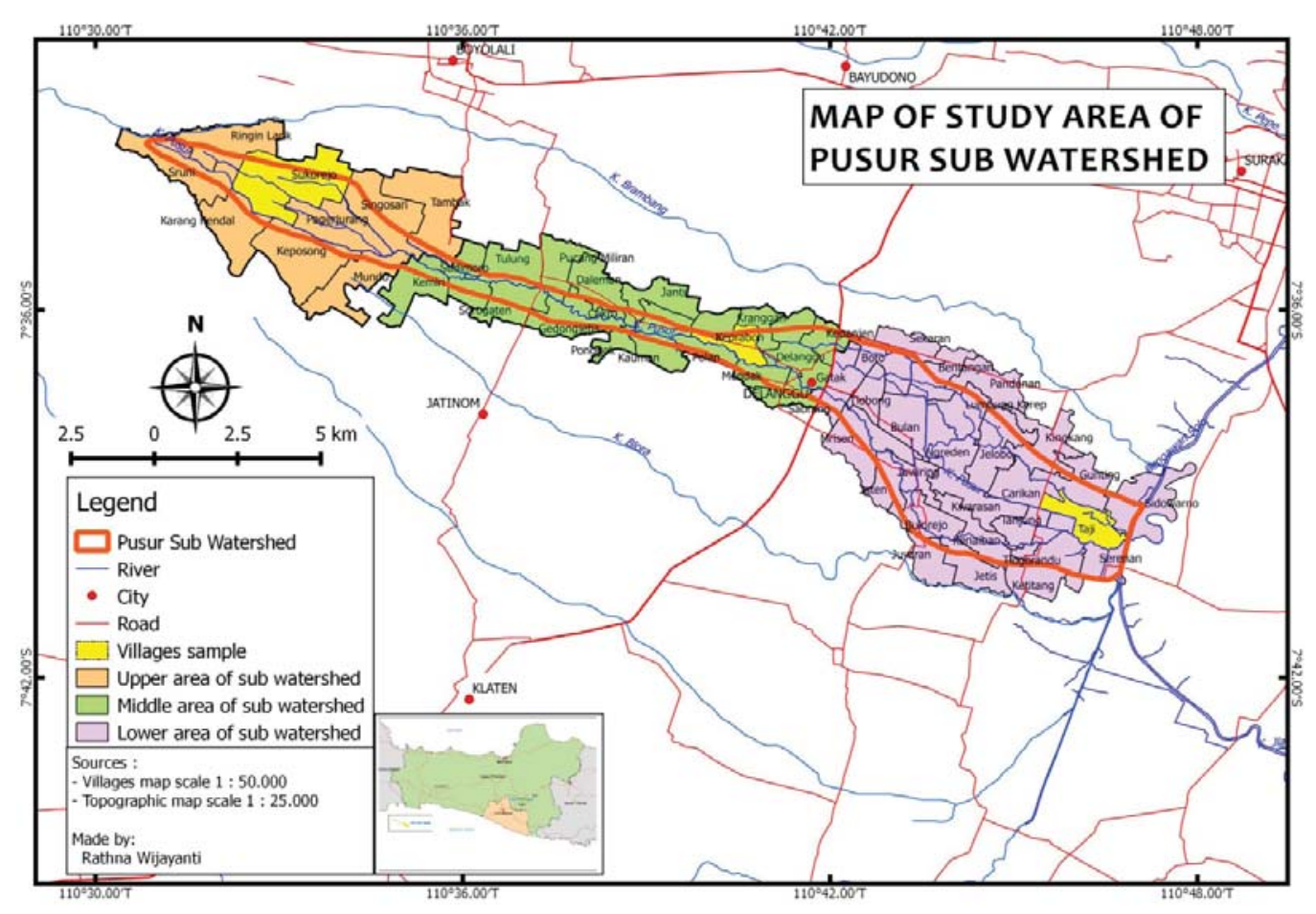

Figure 1. Study area map 
2. Results and Discussion

a. Variety of Water Availability in Pusur Sub-watershed

Field study demonstrated the conditions based on the aspects of quality, quantity, temporal distribution (in the dry and rain season), spatial distribution (sub-watershed division), institution, and water source access. Data on the variety of water availability is presented in Table 1 as follows:

Table 1. Variety of water availability in Pusur sub-watershed

\begin{tabular}{|c|c|c|c|c|c|c|}
\hline \multirow{2}{*}{ Description } & \multicolumn{2}{|c|}{ Upper } & \multicolumn{2}{|c|}{ Middle } & \multicolumn{2}{|c|}{ Lower } \\
\hline & Rain & Dry & Rain & Dry & Rain & Dry \\
\hline \multicolumn{7}{|l|}{ Water quality } \\
\hline Ground water & \multicolumn{2}{|c|}{ None } & \multicolumn{2}{|c|}{ Good } & \multicolumn{2}{|c|}{ Good } \\
\hline Irrigation water & \multicolumn{2}{|c|}{ None } & \multicolumn{2}{|c|}{ Moderate } & \multicolumn{2}{|c|}{ Moderate } \\
\hline River water & \multirow{2}{*}{\multicolumn{2}{|c|}{ Poor }} & \multicolumn{2}{|c|}{ Good } & \multicolumn{2}{|c|}{ Moderate } \\
\hline \multicolumn{5}{|l|}{ Water quantity } & & \\
\hline Ground water & \multicolumn{2}{|c|}{ Small/none } & \multicolumn{2}{|c|}{ High } & \multicolumn{2}{|c|}{ High } \\
\hline Irrigation water & \multicolumn{2}{|c|}{ None } & & & Moderate & $\begin{array}{l}\text { None - mod- } \\
\text { erate }\end{array}$ \\
\hline River water & Small & None & & & High & Moderate \\
\hline \multicolumn{7}{|l|}{ Social economy } \\
\hline $\begin{array}{l}\text { Educational back- } \\
\text { ground }\end{array}$ & \multicolumn{2}{|c|}{ Moderate } & \multicolumn{2}{|c|}{ Moderate } & \multicolumn{2}{|c|}{ Low } \\
\hline Social network & \multicolumn{2}{|c|}{ Moderate } & \multicolumn{2}{|c|}{ Moderate } & \multicolumn{2}{|c|}{ Moderate } \\
\hline Conflict & \multicolumn{2}{|c|}{ Low } & \multicolumn{2}{|c|}{ High } & Moderate & High \\
\hline \multicolumn{7}{|l|}{ Institutional } \\
\hline Farmer group & \multicolumn{2}{|c|}{ Good } & \multicolumn{2}{|c|}{ Good } & \multicolumn{2}{|c|}{ Good } \\
\hline $\begin{array}{l}\text { Water regulatory } \\
\text { institution }\end{array}$ & \multicolumn{2}{|c|}{ Good } & \multicolumn{2}{|c|}{ Moderate } & Mc & erate \\
\hline Access & & & & & & \\
\hline Ground water & Inacces & & & & $\mathrm{Ac}$ & ssible \\
\hline Irrigation water & Nor & & & & Moderate & Inaccessible \\
\hline River water & Inaccessible & None & & & & erate \\
\hline
\end{tabular}

Community living in adjacent to the upper area of Pusur sub-watershed had to face the issues of limited water sources for agriculture and insufficient access to water for domestic necessities. Agriculture in this area was solely relied on rainwater since other sources such as irrigation canals and wells were unavailable. For domestic needs, the establishment of groundwater wells was costly, hence, it was unaffordable for major people. People had to buy water either by pipeline system or from tanker trucks, which certainly such burden for the community.

In contrary to upper area, middle area had plentiful water supply, whether from springs, rivers, and irrigation canals. More than 90\% of paddy fields in this area could be reached by irrigation canals. In addition, numbers of springs were available for the community necessities. Livelihood vulnerability in middle area was due to the water excess that was not supported by efficient regulation and utilization, the low water quality due to poor sanitation and sewage systems, the community's habit in discharging trash into water bodies, and intensive conflicts among community.

In fact, there were several industries such as tofu and sago industries that discharged their wastes directly and regularly into water bodies, which gradually declined water quality. In addition, fishery was hampered as the result of low water quality due to the saturation of pesticide and high potassium content generated from string factory at upper area. Consequently, fish could not be bred. Furthermore, the community habit in throwing domestic trash into river was persistent. Survey in 2016 showed houses on the riverbank did not have septic tank and discharged wastes and domestic garages directly into the river. At several areas, cattle were built on the riverbank where wastes were discharged directly into the river. 
For households' domestic needs, the community utilized wells, PDAM (public water utility), and PAMSIMAS (Communitybased Drinking Water Supply and Sanitation). PAMSIMAS is a program of the Ministry of Public Works and NGOs initiated in 2012 as the response of coli bacterial contamination on wells due to poor sanitation. Nowadays, most households facilitate their house with proper toilets although some practiced open defecation in Pusur River.

In the rainy season, declined productivity occurred due to the flooding as the consequence of relatively flat paddy fields. In fact, the first planting season seldom endured prolonged flooding that caused lower productivity in compared to the harvests of the second and third planting season. According to the respondents, adaptation was done by selecting paddy varieties whose stems were relatively low so they stood still during the flooding. Another problem was the conflict of water utilization between local community, particularly farmers, and PT. Tirta Investama since its operation in 2002. It is a part of multinational company, Aqua Danone Group, which has license for water privatization and production of Bottled Drinking Water from ground water in the area. Local community perceived the primary cause for water deficit in the last few years was the result of ground water exploitation that declined water quantity in Pusur sub-watershed and its neighborhood (Meida, 2012).
Lower area used to gain adequate water for irrigation, but recently it harvested paddy once or twice per year. The third planting season (MT III) could not be performed due to the absence of supplementary irrigation neither from groundwater nor river water (Sosiawan and Kartiwa, 2011). Ineffective water management system had led to the uneven water distribution. Ultimately, it triggered both horizontal and vertical conflicts among community members, which potentially extended into vast social crisis. Lower paddy productivity due to the lack of irrigation water also threatened food resilience.

\section{b. Community's Livelihood Strategies to Address Water Vulnerability}

In accordance to data collection in the field via questionnaire (Table 3), in overall, respondents with 15-30 years of experience dominated the total respondents, amounted to $52.94 \%$. It indicated most of them had experience in the agricultural sector. In addition, respondent with high school education level was $33.01 \%$ and with elementary education level was $31.37 \%$. Respondent with high school education level and had 15-30 years experience was $29.63 \%$. From this profile, livelihood strategies were dominated by respondents who had experience in agricultural sector and moderate education level.

Table 2. Respondents' profile based on educational background and experience in the agricultural sector.

\begin{tabular}{|c|c|c|c|c|c|c|c|}
\hline \multirow[b]{2}{*}{ Study area } & \multirow[b]{2}{*}{$\begin{array}{l}\text { Experience in } \\
\text { agriculture }\end{array}$} & \multicolumn{5}{|c|}{ Educational Background (\%) } & \multirow[b]{2}{*}{ Total $(\%)$} \\
\hline & & Non-formal & Elementary & $\begin{array}{c}\text { Junior } \\
\text { High }\end{array}$ & $\begin{array}{l}\text { Senior } \\
\text { High }\end{array}$ & University & \\
\hline \multirow[t]{6}{*}{ Upper } & $<5$ years & 0.00 & 0.00 & 0.00 & 8.57 & 2.86 & 11.43 \\
\hline & $5-10$ & 0.00 & 0.00 & 0.00 & 0.00 & 0.00 & 0.00 \\
\hline & $10-15$ & 0.00 & 0.00 & 0.00 & 8.57 & 0.00 & 8.57 \\
\hline & $15-30$ & 5.71 & 17.14 & 20.00 & 20.00 & 2.86 & 65.71 \\
\hline & $>30$ & 2.86 & 11.43 & 0.00 & 0.00 & 0.00 & 14.29 \\
\hline & Sub total & 8.57 & 28.57 & 20.00 & 37.14 & 5.71 & 100.00 \\
\hline \multirow[t]{6}{*}{ Middle } & $<5$ years & 0.00 & 0.00 & 3.13 & 6.25 & 0.00 & 9.38 \\
\hline & $5-10$ & 0.00 & 0.00 & 3.13 & 3.13 & 0.00 & 6.25 \\
\hline & $10-15$ & 0.00 & 3.13 & 3.13 & 15.63 & 0.00 & 21.88 \\
\hline & $15-30$ & 0.00 & 31.25 & 3.13 & 18.75 & 6.25 & 59.38 \\
\hline & $>30$ & 0.00 & 0.00 & 0.00 & 3.13 & 0.00 & 3.13 \\
\hline & Sub total & 0.00 & 34.38 & 12.50 & 46.88 & 6.25 & 100.00 \\
\hline \multirow[t]{2}{*}{ Lower } & $<5$ years & 0.00 & 8.57 & 8.57 & 2.86 & 0.00 & 20.00 \\
\hline & $5-10$ & 0.00 & 8.57 & 5.71 & 2.86 & 0.00 & 17.14 \\
\hline
\end{tabular}




\begin{tabular}{|c|c|c|c|c|c|c|c|}
\hline \multirow[b]{2}{*}{ Study area } & \multirow{2}{*}{$\begin{array}{l}\text { Experience in } \\
\text { agriculture }\end{array}$} & \multicolumn{5}{|c|}{ Educational Background (\%) } & \multirow[b]{2}{*}{ Total $(\%)$} \\
\hline & & Non-formal & Elementary & $\begin{array}{l}\text { Junior } \\
\text { High }\end{array}$ & $\begin{array}{l}\text { Senior } \\
\text { High }\end{array}$ & University & \\
\hline & $10-15$ & 14.29 & 5.71 & 2.86 & 0.00 & 0.00 & 22.86 \\
\hline & $15-30$ & 5.71 & 11.43 & 2.86 & 8.57 & 5.71 & 34,29 \\
\hline & $>30$ & 2.86 & 0.00 & 0.00 & 2.86 & 0.00 & 5.71 \\
\hline & Sub total & 22.86 & 34.29 & 20.00 & 17.14 & 5.71 & 100.00 \\
\hline & Total : & 10.78 & 32.35 & 17.65 & 33.33 & 5.88 & 100.00 \\
\hline
\end{tabular}

Source: Primary data, 2016.

Livelihood vulnerability related to water availability urged the community to have capacity in improving strategy to confront the situation. Strategy was a must to address the period of water shortage. In case it occurred, respondents had several adaptation strategies. Adaptation strategies for water availability can be in the form of reaction and anticipation (Winarto, 2013; World Bank, 2010).

\section{1) Farmers' reaction/response during water deficit for agriculture}

The reactions specified by the respondents could be classified as reckless and careless as well as merely based on impulse and public perception. In contrast to the responsive concept that is emphasized on holistic contemplation, measured actions or attitudes that consider the pros and cons, good and bad, or considerate the effects and influences (KBBI, 2016). Respondents' reactions or responses when water deficit occurred are presented in Table 3. Diverse options were based on their experiences in preparing and recognizing the area and its environmental factors.

Table 3. Farmers' reactions/responses during water deficit

\begin{tabular}{llccc}
\hline & \multicolumn{2}{c}{ Reaction/response } & \multicolumn{2}{c}{ Answer (\%) } \\
\cline { 3 - 5 } & & Upper & Middle & Lower \\
\hline 1) & Uncultivated land (fallow) & 68.57 & 9.38 & 57.14 \\
2) & Non-agricultural activities & 8.57 & 25.00 & 25.71 \\
3) & Establishment of wells & 0.00 & 43.75 & 20.00 \\
4) & River water for irrigation & 0.00 & 65.63 & 57.14 \\
\hline
\end{tabular}

Source: Primary data, 2016.

\section{a) Uncultivated land (fallow)}

Fallowing is leaving the agricultural land uncultivated that is opted when irrigation is inadequate. Field study demonstrated $68.57 \%$ respondents from upper area preferred to leave the land uncultivated due to the absence of alternative water resources for agriculture except from rainwater. Nevertheless, few respondents $(9.38 \%)$ from middle area who chose this option since almost all fields were provided by irrigation canals. While $57.14 \%$ respondents from lower area did not have access to river water and preferred this fallowing due to the high cost of renting pumps.

\section{b) Non-agricultural activities}

Small number of respondents from upper area $(8.57 \%)$ preferred to look for nonagricultural activities. Types of crops on their land are classified as less time-consuming, thus, they were more preoccupied on cattle, seedling preparation/nursery, bamboo craft, and others. Those activities were conducted by $25 \%$ respondents from middle area and $25.71 \%$ respondents from lower area. Most of them were engaged in home industry such as horn handicraft, bamboo fan, gamelan, tradition house wares, souvenirs, wallets, clutches, clusters and wayang puppets.

Communities with the skills, expertise, or sufficient education had options to work at and to gain revenue from non-agricultural sectors. In fact, education and skills/expertise outside of agricultural sector were capable to anticipate the declined land for agriculture. Respondents with high school or similar certificate would have opportunity to work at factories in Klaten, Boyolali, and Sukoharjo. Several activities were also preferred by respondents who had skill and expertise at the time they were off from planting-harvesting activities, such as being the worker for buildings and factories outside their villagec) 


\section{c) Establishing wells}

The establishment of wells was not chosen by respondents from upper area since it was unaffordable for them. To attain groundwater, they had to drill the ground over 100 meters in depth. A total of $43.75 \%$ respondents from middle area intended to make wells if water deficit occurred. Pumps had also been prepared by the village officers as anticipation. Wellmaintained irrigation canals could provide irrigation throughout the year. Nevertheless, only $20 \%$ respondents from lower area chose to make wells. They were farmers who did not have any access to irrigation or river water in the dry season in which they usually built communal wells.

\section{d) Pumping river water for irrigation}

Pumping river water could not be practiced by the respondents from upper area since the river was drought. It was done by $65.63 \%$ respondents from middle area and $57.14 \%$ respondents from lower area. However, when it was carried out by the farmers of middle area, it triggered conflict with the farmers of lower area since they needed river as the source of supplementary irrigation. In addition, not the entire farmers of lower area were allowed to pump river water, only those at the downstream of Pusur River or Bengawan Solo.

\section{2) Anticipation}

Anticipation is measurement of things that will occur or have not occurred (KBBI, 2016). Anticipation carried out by the community when water deficit occurred in their land is presented in Table 4:

Table 4. Anticipation carried out by local community

\begin{tabular}{lccc}
\hline \multicolumn{1}{c}{ Anticipation } & \multicolumn{3}{c}{ Answer (\%) } \\
\cline { 2 - 4 } & Upper & Middle & Lower \\
\hline 1) Shifting the planting season & 62.86 & 65.63 & 54.29 \\
2) Selecting drought-resistant crops & 82.86 & 34.38 & 34.29 \\
3) Crop diversification in one season & 80.00 & 12.50 & 22.86 \\
4) Preparing rain water reservoir & 97,14 & 9,38 & 17,14 \\
5) Preparing wells and pumps & 0,00 & 59.38 & 80.00 \\
6) Improving/maintaining irrigation canals & 0.00 & 87.50 & 85.71 \\
7) Improving irrigation water system & 0.00 & 43.75 & 48.57 \\
8) Empowering water regulator institution & 5.71 & 50.00 & 17.14 \\
9) Empowering farmer group & 8.57 & 68.75 & 34.29 \\
10) Making agreement on water consumption & 5.71 & 65.63 & 40.00 \\
regulation & & & \\
\hline
\end{tabular}
Source: Primary data, 2016.

\section{a) Shifting the planting season}

As an anticipatory action when water deficit is estimated including due to the delayed rain season, as many as $62.86 \%$ respondents from upper area opted to shift the planting season. Similarly, it was opted by $65.63 \%$ respondents from middle and $54.29 \%$ respondents from lower area. In addition to water availability factor, limited number of farmers also caused the shifting of planting season and the difficulty of collective cropping system.

\section{b) Selecting drought-resistant types of crop}

A total of $82.86 \%$ of respondents in upper area selected certain types of crop whose characteristics were water-saving and drought-resistant since the only water source was rain water. The types included perennials and secondary crops (palawija). Respondents from middle and lower area are the farmers of wetlands monoculture systems in which the cropping pattern throughout the year is paddy-paddy-paddy. There were $34.38 \%$ of respondents from middle area and $54.29 \%$ from lower area, opted drought-resistant varieties that can survive with small amount of water

\section{c) Crop diversification system in one season}

Another strategy that would be and had been practiced by the respondents from upper area in anticipating water deficit was crop diversification in one planting season or agroforestry system. A total of $80 \%$ respondents chose this strategy because it had been evidenced to optimize the land productivity and to obtain a sustainable harvest throughout the year. However, it was less desirable for respondents from middle and lower area since 
the tradition of paddy's cultivation throughout the year.

\section{d) Preparing rain water reservoir}

The provision of water for livestock such as for feeding, drinking, and bathing, was supplied from large tanks that could catch high amount of rainwater until the next rain season. Approximately five years ago, those tanks were also utilized for domestic needs. Nevertheless, in the development, the community obtained the water by purchasing water with a price of Rp80,000.00 per tank or amounted to 6,000 liters (in 2016). For domestic and cattle needs, each household approximately required four water tanks with a total of Rp250,000.00/month.

Subsequently, several households and private parties had capacity to afford the establishment of groundwater wells with a depth approximately 120 meters. Water was pumped from wells and distributed through pipes into houses where each of them was equipped with water-meters to record the monthly consumption. Community contributed this system by paying for Rp6,000.00/ m3 of consumed water.

\section{e) Preparing wells and pumps}

Wells and pumps were important stuffs particularly for the respondents from lower area (80\%). Water obtained from wells and pumped from rivers was used to irrigate paddy fields, especially in the dry season since water from irrigation was inadequate. For respondents from upper area, preparation of wells and pumps was unnecessary since groundwater was extremely difficult to be attained, which made it cost-ineffective choice.

\section{f) Improving/maintaining irrigation canals}

A total of $87.50 \%$ respondents from upper area and $85.71 \%$ respondents from lower area preferred the strategy to improve/maintain irrigation canals as anticipation of water deficit, meanwhile respondents from upper area had different opinion due to the absence of access to canals. Field observation showed tertiary irrigation canals in the middle area became community's responsibility in case there was a leakage, consequently, the village's expenditure for maintaining irrigation embankments was too high (primary data, 2016).

Due to numbers of water resources, the maintenance of irrigation system was prioritized as the effort to enhance the agricultural yield. Before 2005, irrigation canals system was poor, water leaks frequently occurred, and agricultural land endured irrigation shortage in the dry season. Currently, most of paddy fields gained sufficient water throughout the year. In contrast with middle area, the improvement of irrigation canals in lower area was performed by the farmers, the improvement was performed improperly by the irrigation maintenance team, water regulation was carried out ineffectively, and irrigation system was done inefficiently.

\section{g) Improving the efficiency of irrigation water system}

Efficiency of irrigation system was intended to ensure the water supply especially in the dry season. However, $43.73 \%$ respondents from middle area and $48.57 \%$ from lower area chose this strategy, while there was no irrigation system in upper area. Due to plenty water in middle area, efficiency was conducted by improving and maintaining irrigation canals to prevent leakage. In lower area, it was done by optimally employed limited number of available irrigation canals, particularly for irrigating paddy fields to reduce the pumping frequency.

\section{h) Empowering Water regu-latory institution and farmer group}

Empowerment of water regulatory institution was presumed to be significant by $50 \%$ respondents from middle area and $17.14 \%$ respondents from lower area mainly due to the collective necessity for water. The members of both institution and farmer group are both the land-owner and tenants. Both of them accommodated various aspirations and actions regarding with the members' interests. For the community of upper area, water regulatory institution was considered less vital due to the absence of irrigation system.

\section{i) Agreement concerning with water regulation/consumption}

Agreement concerning with water regulation for irrigation was crucial for $65.63 \%$ respondents from middle area and 40\% respondent from lower area. Moreover, it was prevailed in the dry season or the third planting season. Based on field study, water regulation was vulnerable issue to create conflict among the farmers. For the community of lower area, vulnerability level for conflict was higher in compared with middle area as the consequence of limited water resources.

\section{Conclusions}

a. Water availability in the upper, middle, lower part of Pusur sub-watershed varied as the result of diverse quality, quantity, temporal distribution, spatial distribution, social-economy, and institutional aspect. 
The quantity of water became a major concern in the upper and lower area, while the quality was the problem in the middle area.

b. Regarding with water availability, several livelihood strategies were made as the adaption in the form of reaction and anticipation. Leaving the land as fallow or uncultivated was preferred by the farmer in the upper area due to the unfeasibility of new water resources, meanwhile, pumping the wells and rivers was reaction of people in the middle and lower area in facing water deficit. Anticipation was carried out by crop diversification with agroforestry system that was selected by farmers in upper area since this system successfully optimized land productivity regardless the irrigated water and provided high economical and ecological value. In addition, the improvement and maintenance of irrigation canals was preferred by the farmers in middle area and the preparation of wells and pumps by the farmers in lower area.

\section{References}

Baiquni, M., 2006, Pengelolaan Sumberdaya Perdesaan dan Strategi Penghidupan Rumah Tangga di Propinsi Daerah Istimewa Yogyakarta pada Masa Krisis (1998-2003), Disertation: Universitas Gadjah Mada.

Bank Dunia, 2010, "Adaptasi terhadap Perubahan Iklim", accessed at: http:// siteresources. w orld bank. or g / I N T I N D O NES I A / R e s o u r c es / Plication/280016-1235115695188/5847179-1258084722370/Adaptasi.terhadap.Perubahan. Iklim.pdf, on 20 April 2016.

Chambers R. \& Conway, G. R. 1992. Sustainable Rural Livelihoods: Practical Concepts for the 21st Century, University of Sussex, Working Paper No. 296, Brighton: IDS.

Depdiknas, 2008, “Kamus Besar Bahasa Indonesia”, Gramedia Pustaka Indonesia.

DFID, 2001, Sustainable Livelihoods Guidance Sheets, Number 1-8, London: Department for International Development (UK), London (accessesd at: www.livelihoods.org).

Dirjen RLPS, 2009, Peraturan Direktur Jenderal Rehabilitasi Lahan dan Perhutanan Sosial No.: P.04/VSET/2009 tentang Pedoman Monitoring dan Evaluasi DAS, Jakarta.

Ellis, F., 2000, Rural Livelihoods and Diversity in Developing Countries, Oxford University Press.

Eureka Pendidikan, 2015, accessed on 18 September 2016 at: http://www.eurekapendidikan. com/2015/09/defenisi-sampling-dan-teknik-sampling.html

FAO, 2007, Why Invest in Watershed Management?, Food and Agricultural Organisation, Rome, Italy.

Khan, Tahir Husnain, 2014, Water scarcity and its impact on agriculture, Case Study of Layyah, Pakistan, Department of Urban and Rural Development.

Harsoyo, B., 2011, Konsep Air Virtual (Virtual Water Concept): Jurnal Sains E Teknologi Modifikasi Cuaca, Vol. 12, No. 1, 2011: 25-32.

Meida, A.N., 2012, Konflik Antar Sektor di Kabupaten Klaten, accessed at: http:/ /www.kompasiana. com/avidnurmeida/konflik-antarsektor-di-kabupaten-klaten_551077c6a333119737ba82e8, on 30 December 2015.

Sosiawan, H., and Subagyono, K., 2009, Strategi Pembagian Air secara Proporsional untuk Keberlanjutan Pemanfaatan Air: Jurnal Pengembangan Inovasi Pertanian 2(4), 2009: 299-305, Bogor.

Sosiawan, H., and Kartiwa, B., 2011, Pengelolaan Sumber Daya Air Terpadu di Kabupaten Klaten, Tinjauan dari Aspek Hidrologi", Buletin Hasil Penelitian Agroklimat dan Hidrologi Volume 8: 41-45.

Scoones, I., 1998, Sustainable Rural Livelihoods: A Framework for Analysis, University of Sussex, Institute of Development Studies, Working Paper No. 72, Brighton: IDS.

Scale Up dan Ford Foundation, 2011, Konflik Sumber Daya Alam dan Penghidupan yang Berkelanjutan, Buletin Scale Up Edisi II/2011, accessed at: www.scaleup.or.id, on 9 November 2015.

Winarto, 2013, Strategi Adaptasi Masyarakat terhadap Perubahan Iklim: sebuah Pendekatan Holistik dan Integratif, accessed at: http:/ / winarto.in/2013/03/strategi-adaptasi-masyarakat-terhadap- 
perubahan-iklim-sebuah-pendekatan-holistis-dan-integratif/, on 19 April 2016.

\section{Appendix}

Appendix 1. Research objectives, variables, data, sources of data, and analysis.

\begin{tabular}{|c|c|c|c|c|}
\hline Objective & Variable & Measured data & $\begin{array}{c}\text { Sources and data } \\
\text { collection methods }\end{array}$ & Analysis \\
\hline \multirow[t]{6}{*}{$\begin{array}{l}\text { Water } \\
\text { availability }\end{array}$} & Water quality & $\begin{array}{l}\text { The quality of water used for } \\
\text { domestic and agriculture. }\end{array}$ & & \\
\hline & Water quantity & $\begin{array}{l}\text { The quantity of water } \\
\text { demanded by domestic } \\
\text { activities and agricultural } \\
\text { sector. }\end{array}$ & & \\
\hline & Social economy & $\begin{array}{l}\text { Educational background of } \\
\text { respondents; Social network } \\
\text { assessed from the utilization } \\
\text { of communication means, } \\
\text { internet, and media social; } \\
\text { Conflict evaluated from the } \\
\text { frequency of conflict. }\end{array}$ & $\begin{array}{l}\text { - Interview in } \\
\text { the form of } \\
\text { questionnaire; } \\
\text { - In-depth interview; } \\
\text { - Field observation }\end{array}$ & $\begin{array}{l}\text { Quantitative } \\
\text { and Qualitative } \\
\text { descriptive }\end{array}$ \\
\hline & Institution & $\begin{array}{l}\text { Activities participated by } \\
\text { farmer groups and water } \\
\text { regulatory management. }\end{array}$ & - Secondary data & \\
\hline & Access to water & Access to reach water sources & & \\
\hline & Temporal & $\begin{array}{l}\text { Conditions in the dry and rain } \\
\text { season. }\end{array}$ & & \\
\hline \multirow[t]{11}{*}{$\begin{array}{l}\text { Community } \\
\text { livelihood } \\
\text { strategies }\end{array}$} & $\begin{array}{l}\text { Reaction/ } \\
\text { response }\end{array}$ & - Fallow (uncultivated) & & \\
\hline & & $\begin{array}{l}\text { - Non-agricultural activities } \\
\text { - Drilling wells } \\
\text { - Pumping water from rivers } \\
\text { for irrigation }\end{array}$ & & \\
\hline & Anticipation & $\begin{array}{l}\text { - Shifting the planting } \\
\text { season } \\
\text { - Selecting drought-resistant } \\
\text { crops }\end{array}$ & & \\
\hline & & $\begin{array}{l}\text { - Crop diversification in one } \\
\text { season }\end{array}$ & $\begin{array}{l}\text { Interview in } \\
\text { the form of } \\
\text { questionnaire; }\end{array}$ & \\
\hline & & $\begin{array}{l}\text { Preparation of rainwater } \\
\text { reservoir/tanks }\end{array}$ & - In-depth interview; & $\begin{array}{l}\text { Quantitative } \\
\text { and Qualitative } \\
\text { descriptive }\end{array}$ \\
\hline & & $\begin{array}{l}\text { - Preparation of wells and } \\
\text { pumps }\end{array}$ & - Field observation & \\
\hline & & $\begin{array}{l}\text { - Irrigation system } \\
\text { maintenance }\end{array}$ & - Secondary data & \\
\hline & & $\begin{array}{l}\text { - Efficiency improvement of } \\
\text { irrigation canals system }\end{array}$ & & \\
\hline & & $\begin{array}{l}\text { Empowerment of water } \\
\text { management institution }\end{array}$ & & \\
\hline & & $\begin{array}{l}\text { Empowerment of farmer } \\
\text { group }\end{array}$ & & \\
\hline & & $\begin{array}{l}\text { - Agreement for water } \\
\text { regulatory }\end{array}$ & & \\
\hline
\end{tabular}

